\title{
Macro channel riparian vegetation of the Olifants River System in the Savanna Biome, Mpumalanga
}

\author{
W.J. MyBURGH and G.J. BREDENKAMP
}

Myburgh, W.J. and G.J. Bredenkamp. 2004. Macro channel riparian vegetation of the Olifants River System in the Savanna Biome, Mpumalanga. Koedoe 47(2): 37-60. Pretoria. ISSN 0075-6458.

\begin{abstract}
The vegetation associated with the macro channel of the Olifants River System was investigated to identify plant communities mappable at a spatial scale of 1:250 000. The results obtained by applying the РнҮтотАВ PC classification and mapping program package revealed nine distinct plant communities associated with that section of the river system that flows through the Savanna Biome.
\end{abstract}

Key words: Olifants River System, Savanna Biome, riparian vegetation, plant communities, macro channel, active channel

W.J. Myburgh $\bowtie$, Department of Nature Conservation, Tshwane University of Technology, Pretoria, 0001 Republic of South Africa; G.J. Bredenkamp, Department of Botany, University of Pretoria, Pretoria, 0002 Republic of South Africa.

\section{Introduction}

The Olifants River is one of the most polluted rivers in the Limpopo and Mpumalanga provinces. This pollution is caused by the activities of industry, coal mines, agriculture, towns and villages. Being the second largest river in the former Transvaal, the health of this river system is considered to be of great environmental importance. The initiation of this project was inter alia an attempt to obtain a holistic perspective of the current state of the vegetation associated with the macro channel. Included in the project was the identification of impacts which could lead to the further degradation of the river system (Myburgh 2000, 2001). The negative influence of exotic, alien vegetation is also considered to be of cardinal importance to the well being of the river (Myburgh \& Bredenkamp in prep).

The study was conducted over a period of four years and included a vegetation survey prior to and after flooding events that occurred throughout the system. This paper focuses on the vegetation along the macro channel of the Olifants River System associated with the Savanna Biome and supplements an earlier paper (Myburgh \& Bre- denkamp 2004) describing the vegetation along the Olifants River System associated with the Grassland Biome, at much higher altitudes (Fig. 1).

\section{Study area}

The Savanna Biome section of the Olifants River (Figs. 1 \& 2) refers to that portion of the macro channel from the farm Mooifontein, north of the town Witbank, up to the village Mamba at the border of the Kruger National Park, south east of the town Phalaborwa. The river within the Kruger National Park did not form part of this study. The macro channel of the study area runs through three veld types as described by Acocks (1988), namely: Sourish Mixed Bushveld, Mixed Bushveld and Arid Lowveld (Fig. 1). The catchment area between Loskop Dam and the Drakensberg Mountains, including Sekhukuneland, is described as Mixed bushveld. The mountainous areas represent typical Sourish Mixed Bushveld while the section downstream of J.G. Strydom tunnel is described as Arid Lowveld.

The macro channel of this section of the Olifants River System varies from $17 \mathrm{~m}$ wide 


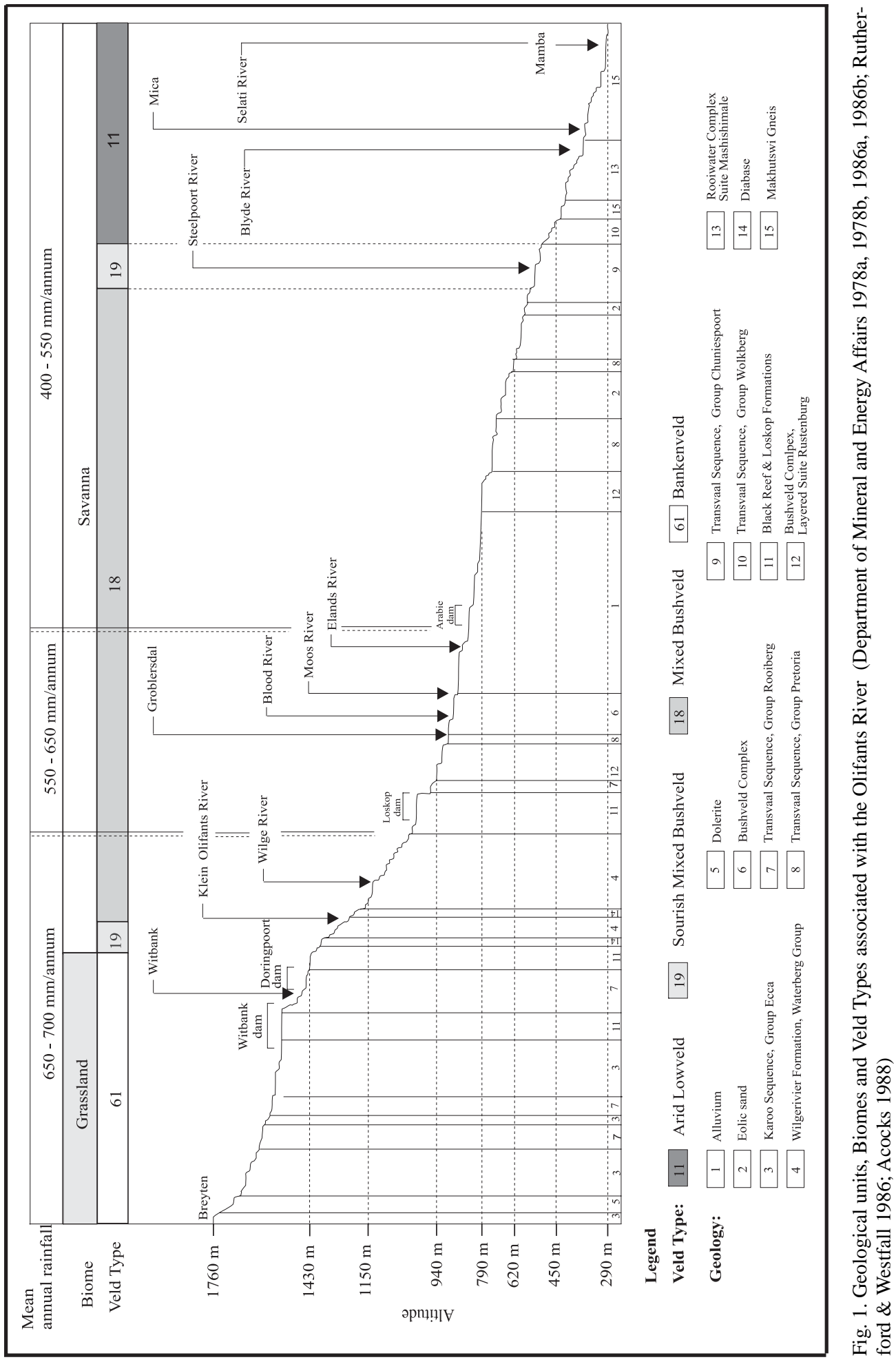




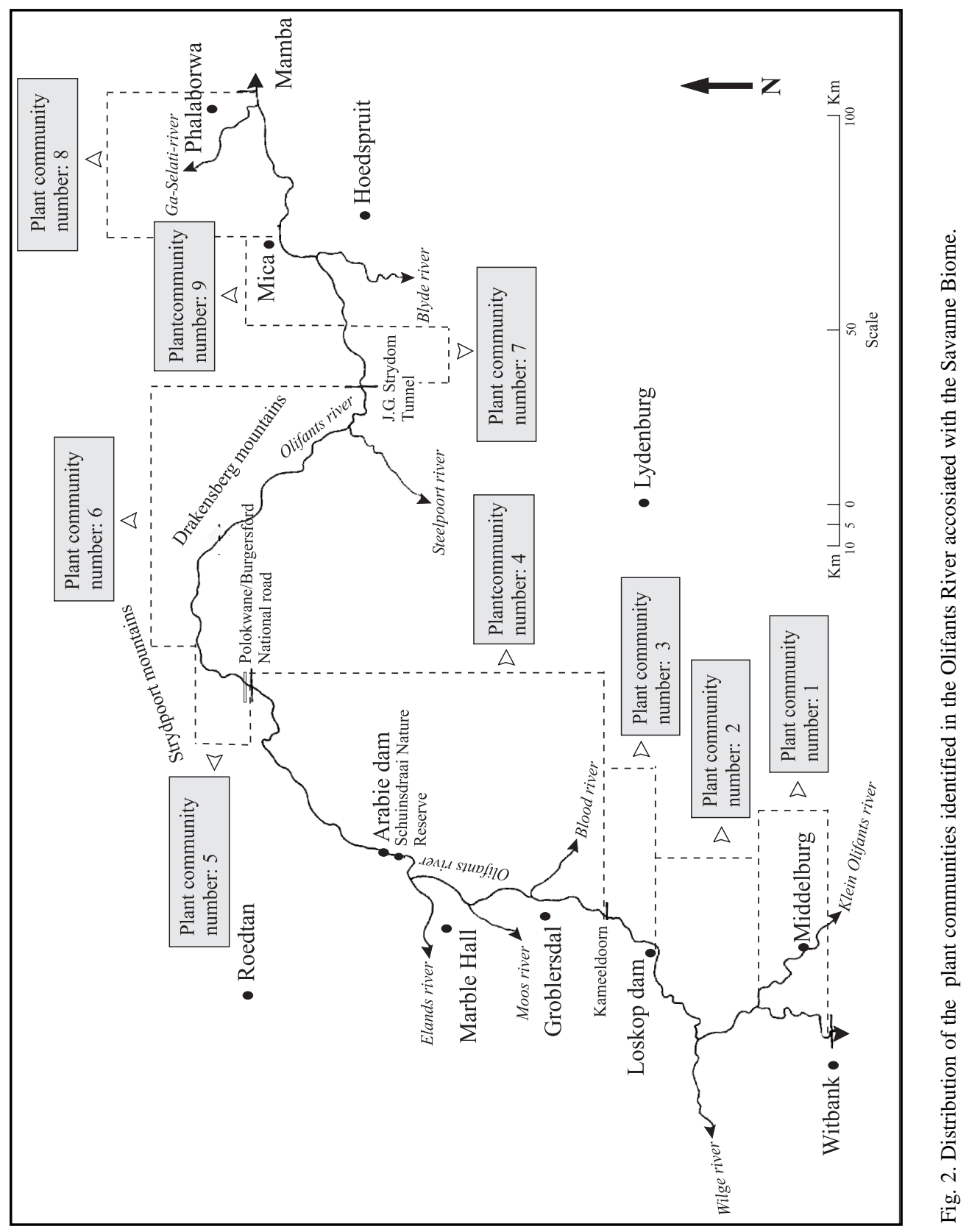




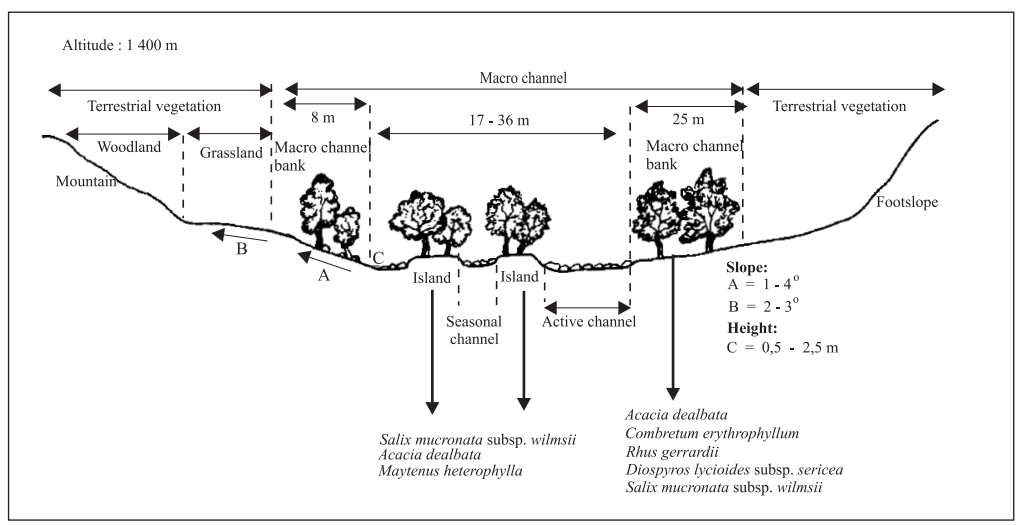

Fig. 3. River profile of the Salix mucronata subsp. wilmsii-Hyparrhenia hirta shrubland.

with a single active channel up to a complex macro channel of $210 \mathrm{~m}$ wide. It is characterised by various channels (active, seasonal and ephemeral) and islands dominated by woody species. The riparian vegetation associated with the macro channel banks is clearly distinguishable from the adjacent terrestrial vegetation.

\section{Methods}

Various researchers (Vannote et. al. 1980; Ward \& Stanford 1983; Naiman et. al. 1988; Townsend 1989) have indicated that riparian vegetation changes from the origin of a river system downstream as the macro channel develops and changes. In the study use was made of a spatial scale of 1:250 000 in order to include the whole section of the Olifants River System, from its origin up to the border of the Kruger National Park. Geology was the most practical empirical dataset available at the mentioned scale and therefore geology was used to stratify the areas through which the river flows (Fig. 1).

The width of the riparian zone varies due to a combination of slope and height of the banks at any given locality (Nilsson et. al. 1994). An area-based vegetation sampling method was used to survey the vegetation. Variable belt transects were located in the stratification (geological) units (Fig. 1). The number of sample plots placed in each stratification unit was proportional to the length of the river within that unit. The width and length of the belt transects were proportional to channel bank width and species richness/growth forms respectively. Floristic and habitat data were collected at 60 geo-referenced sample sites. At most sites a sample plot was placed on both banks of the macro channel, the total data set comprised 119 relevés. The floristic data were analysed by using the PHYTOTAB PC computer program package (Westfall 1990), to identify plant communities.

\section{Results and discussion}

A total of nine clearly recognisable plant communities were identified, mapped and described at a spatial scale of 1:250 000 (Fig. 2) representing the vegetation along the macro channel of the Olifants River System, within the Savanna Biome (Myburgh 2000, 2001).

The plant communities recognised are described below.

\section{The Salix mucronata subsp. wilmsii- Hyparrhenia hirta shrubland}

The Salix mucronata subsp. wilmsii-Hyparrhenia hirta shrubland is represented by five relevés. The distribution of this shrubland community is limited to that section of the Olifants River from Witbank almost to the convergence of the Klein-Olifants and Olifants Rivers (Fig. 2). The distribution is limited to the areas associated with rocks from the Wilgerivier Formation, Waterberg 


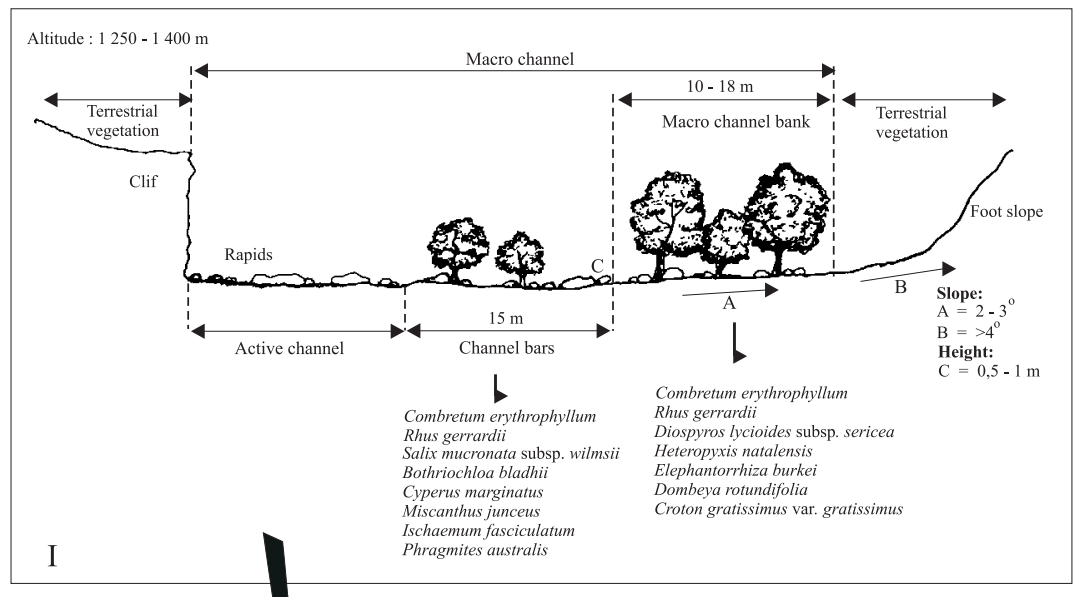

Variation in river profile associated with the Heteropyxis natalensis-Bothriochloa bladhii shrubland

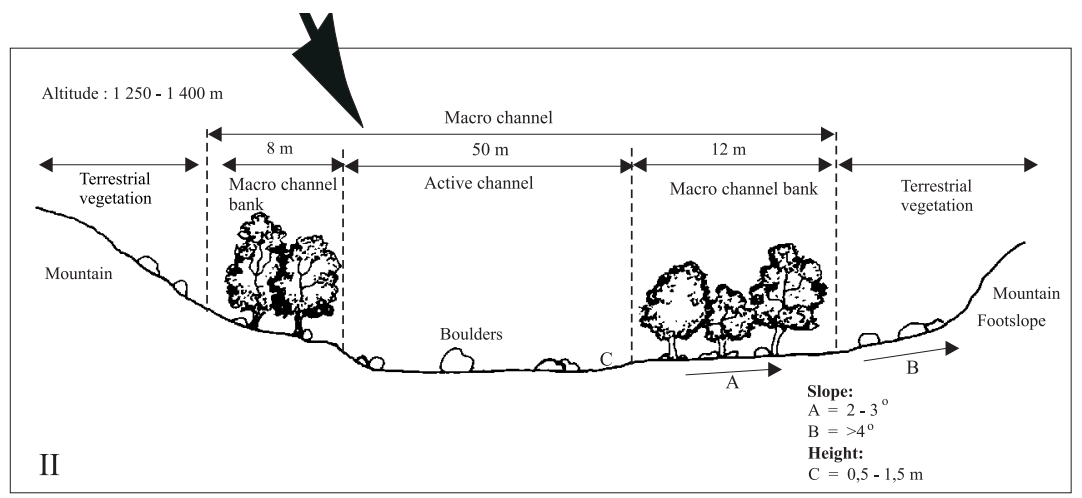

Fig. 4 Variations in river profile associated with the Heteropyxis natalensis-Bothriochloa bladhii shrubland.

Group, at altitudes of about $1400 \mathrm{~m}$ above sea level (Fig. 1). Average soil depth on the macro channel banks is $1200 \mathrm{~mm}$ with texture that varies from loamy sand $(16-20 \%$ clay) to clay soils ( $>55 \%$ clay).

In this section the river meanders through mountainous terrain and the macro channel varies from a single active channel to various channels (active and seasonal), with islands predominantly covered by woody vegetation (Fig. 3). The active channel contains many stagnant pools followed by rapids, where rock cover varies between $10 \%$ to $60 \%$. High-intensity agricultural practices are almost absent and the riparian vegetation is largely natural.

Most of the diagnostic species (Species group 1; Table 1$)$ have low $(<1 \%)$ mean canopy covers with the exception of the forb Hypoestes forskaolii with a canopy cover of $7 \%$. The alien invader Acacia dealbata and the indigenous Combretum erythrophyllum, Salix mucronata subsp. wilmsii en Diospyros lycioides subsp. sericea dominate the tree and shrub layers. The hygrophilous grass species Miscanthus junceus, Ischaemum fasciculatum, Phragmites australis and the sedge Cyperus marginatus dominate the vegetation at the edges of the active channel. 


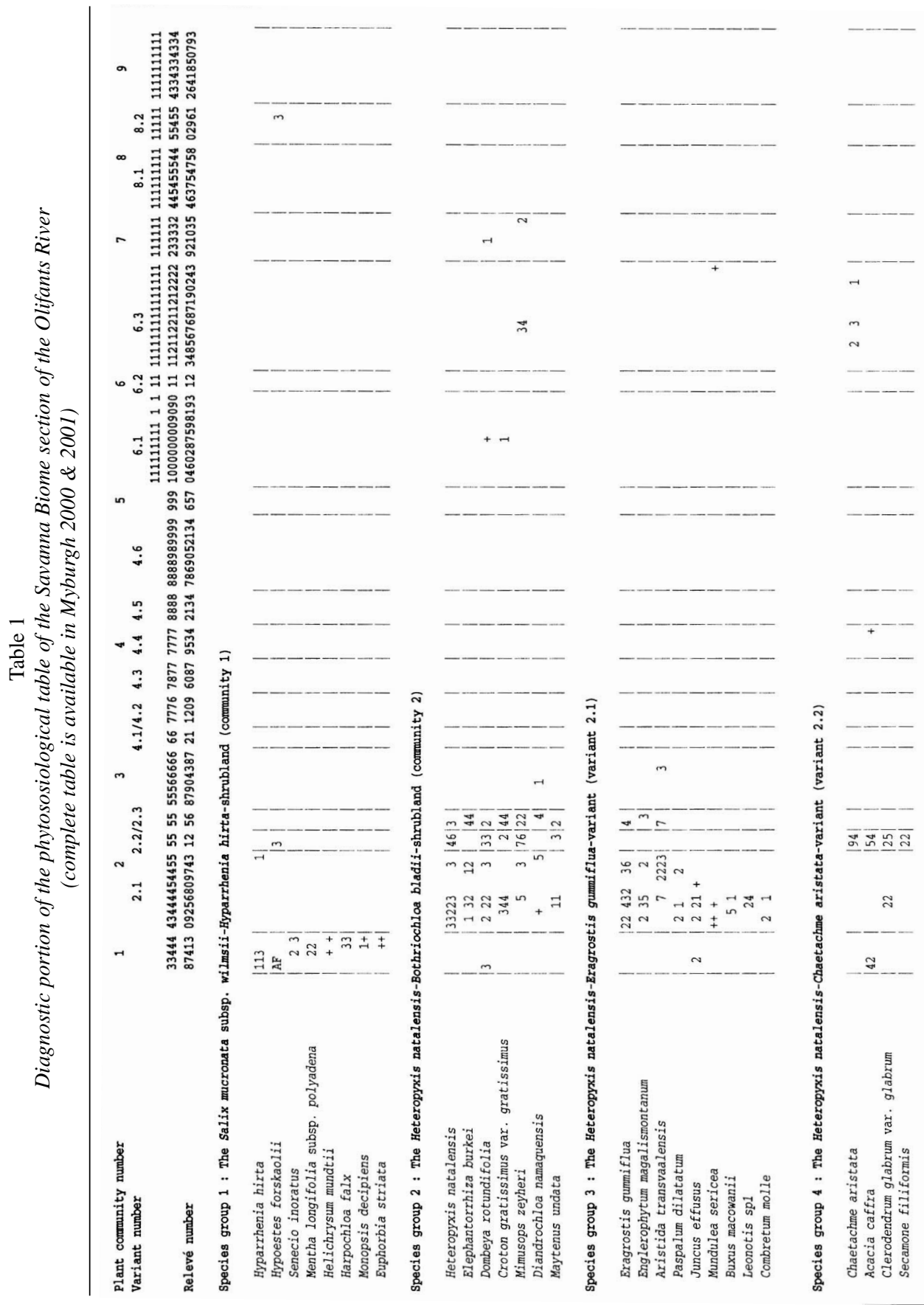




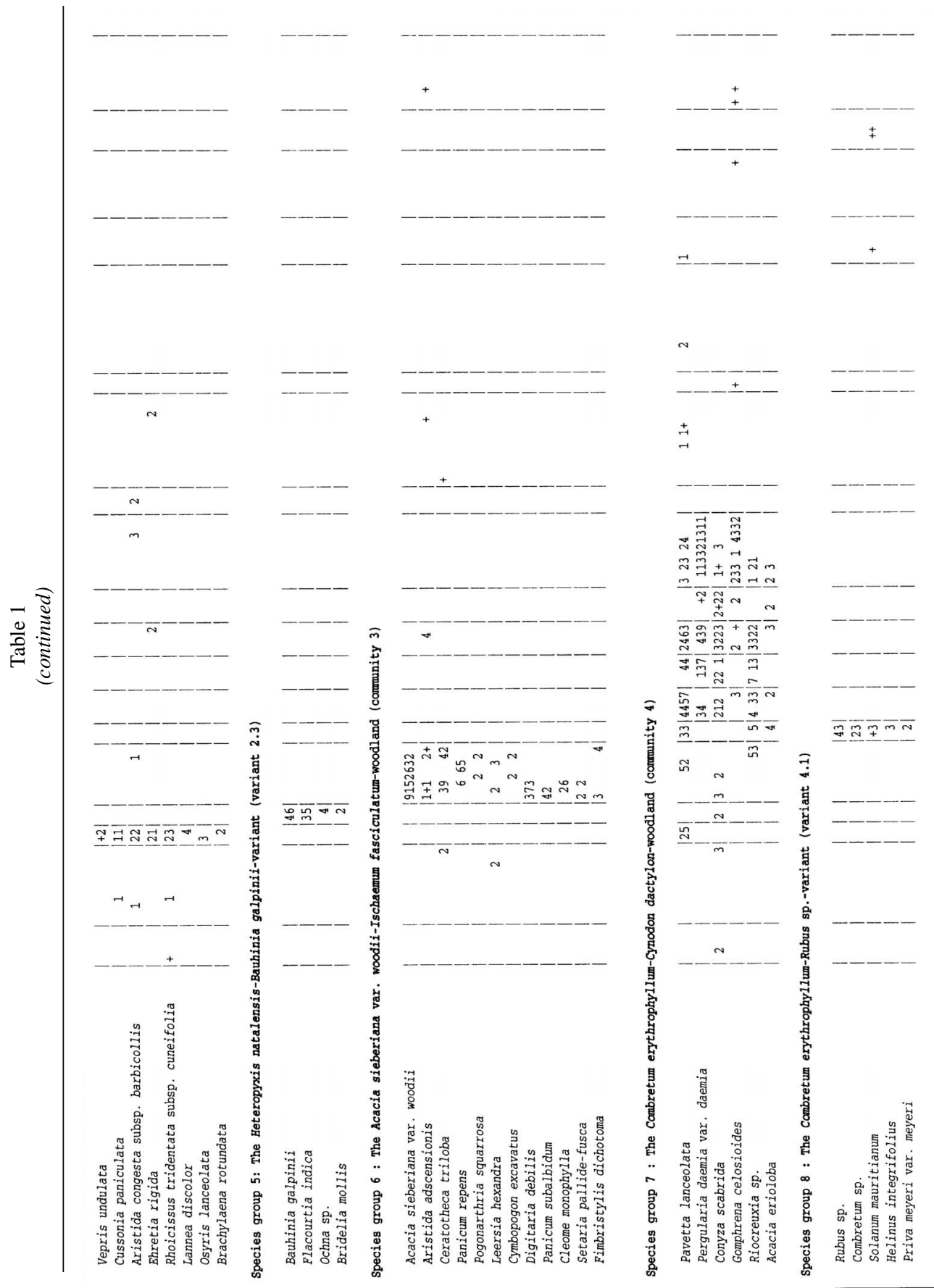




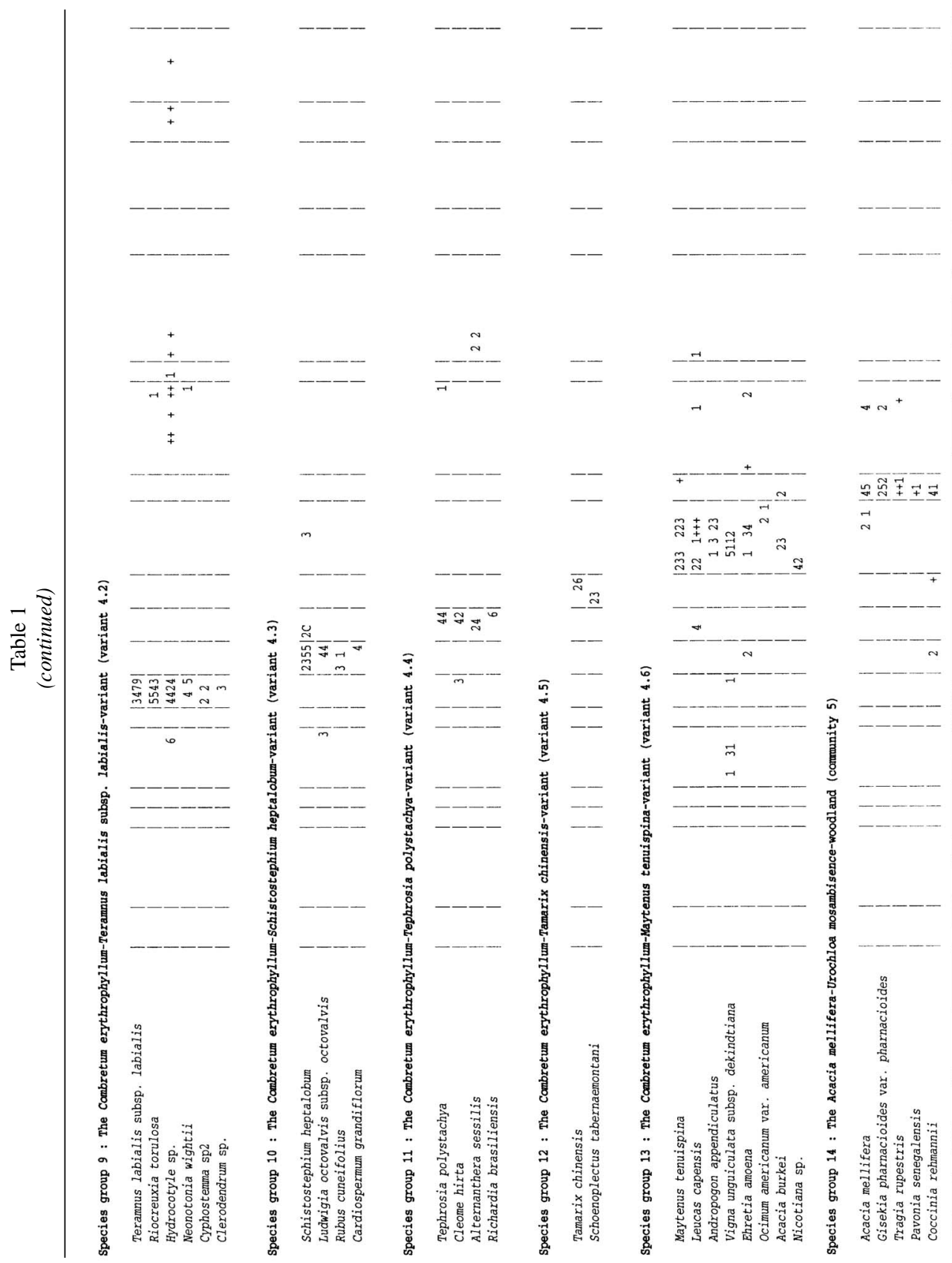




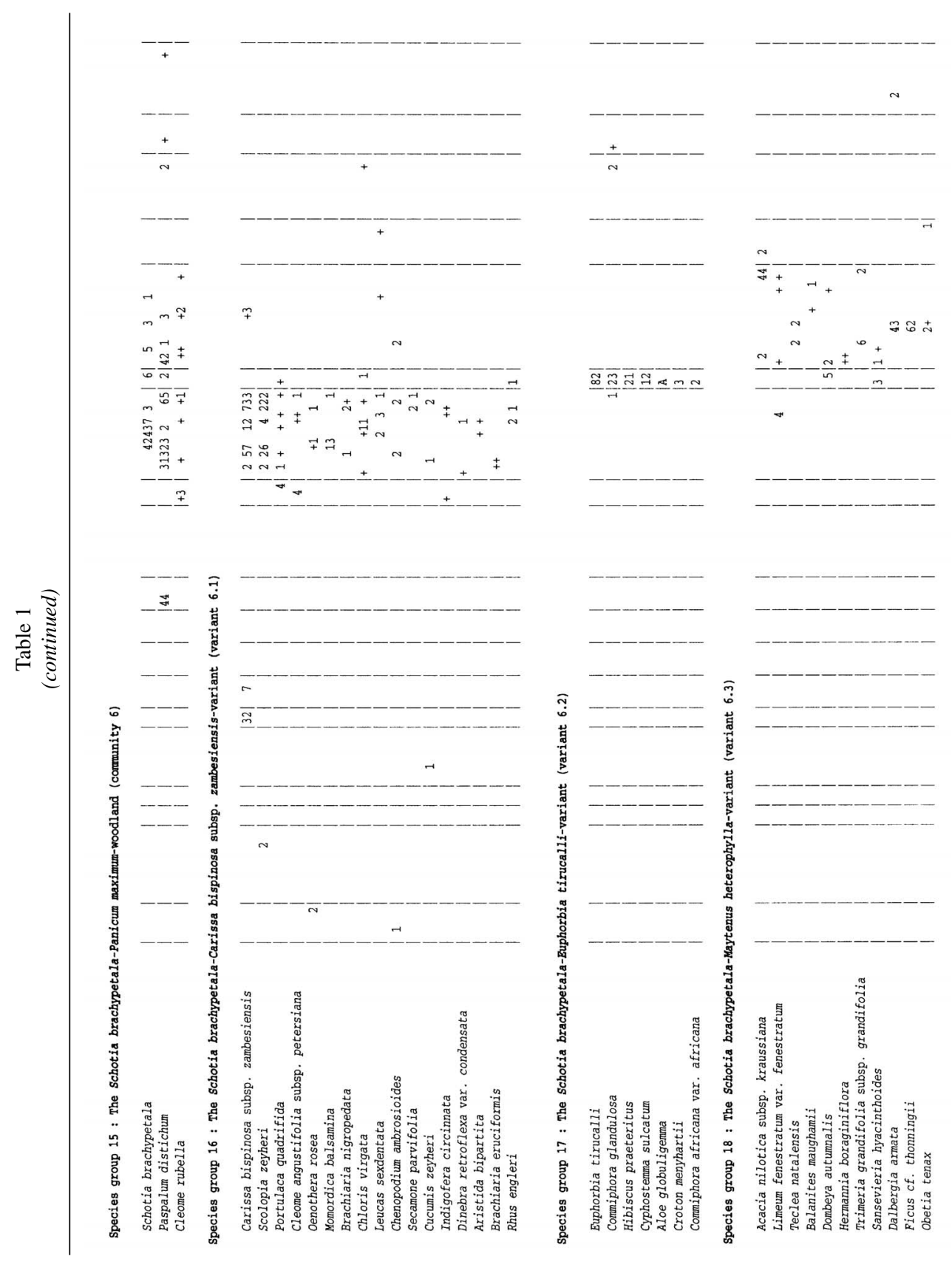




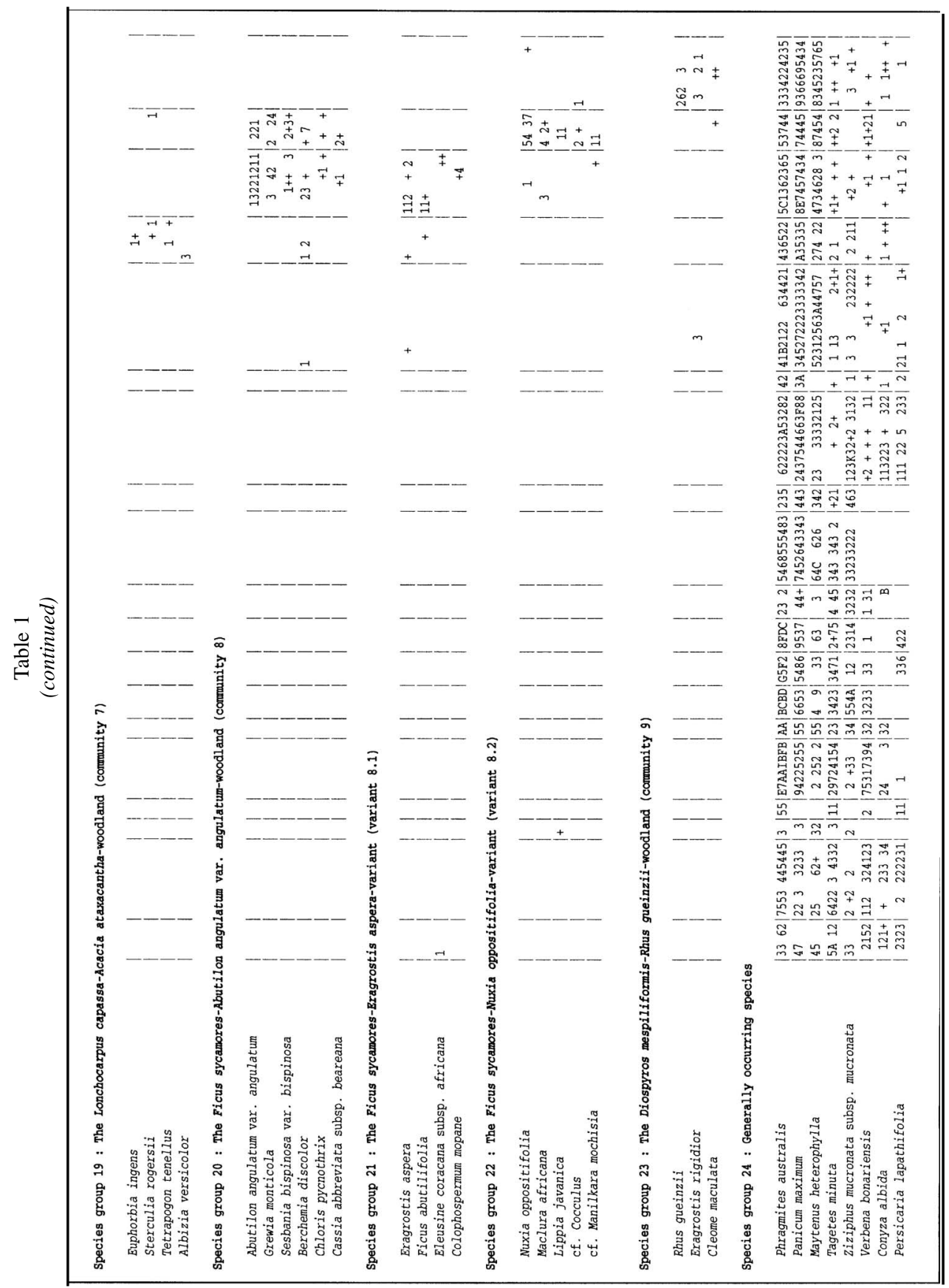


The woody component contributes $25 \%$ to the total mean canopy cover of $55 \%$ of this shrubland community.

\section{The Heteropyxis natalensis-Bothriochloa} bladhii shrubland

The Heteropyxis natalensis-Bothriochloa bladhii shrubland is represented by 15 relevés and is located between the KleinOlifants/Olifants convergence and Loskop Dam (Fig. 2). This community occurs on rocks from the Wilgerivier Formation, Waterberg Group (Fig. 1). The river, which flows through mountainous terrain, descends rapidly from $1400 \mathrm{~m}$ to $1000 \mathrm{~m}$ a.s.l.

This section of the river system represents a transition between the Sourish Mixed Bushveld and the Mixed Bushveld as described by Acocks (1988) and includes three floristical variations. In localised areas vertical cliffs represent the one macro channel bank (Variant 1, Fig. 4) and the riparian species are represented by a few grass, sedge and forb species associated with the edge of the active channel. Soil depth varies between $100 \mathrm{~mm}$ (Heteropyxis natalensis-Bauhinia galpinii variant (2.3) and $1200 \mathrm{~mm}$ (Heteropyxis natalensis-Chaetachme aristata variant (2.2).

The active channel bed is mainly rocky (medium sized rocks up to boulders), with rapids extending over long distances followed by deeper, stagnant pools. Locally, islands separate the active channel from seasonal channels.

Woody diagnostic species (Species group 2; Table 1) of this shrubland include Heteropyxis natalensis, Elephantorrhiza burkei, Dombeya rotundifolia, Croton gratissimus var. gratissimus, Mimusops zeyheri and Maytenus undata. The tree Heteropyxis natalensis has the highest constancy. The tree Combretum erythrophyllum, shrub Salix mucronata subsp. wilmsii, Rhus gerrardii and the dominant grass Bothriochloa bladhii, Miscanthus junceus, Phragmites australis and the sedge Cyperus marginatus are associated with the water edge. The Het- eropyxis natalensis-Bothriochloa bladhii shrubland has a total mean canopy cover of $42 \%$ with the woody species contributing a total of $21 \%$.

\subsection{The Heteropyxis natalensis-Eragros- tis gummiflua variant}

The Heteropyxis natalensis-Eragrostis gummiflua variant is more widely distributed than the Heteropyxis natalensis-Chaetachme aristata variant (variant 2.2) and the Heteropyxis natalensis-Bauhinia galpinii variant (variant 2.3). Soils are predominantly $300 \mathrm{~mm}$ to $450 \mathrm{~mm}$ deep with an aboveground rock cover of between $10 \%$ and $60 \%$, mainly represented by large rocks and boulders.

Diagnostic species for this variant include the tree Combretum molle, the shrubs Englerophytum magalismontanum, Mundulea sericea, the dwarf shrubs Buxus macowanii, Leonotis sp. and the grasses Eragrostis gummiflua, Aristida transvaalensis and Paspalum dilatatum. The tree Combretum erythrophyllum and shrub Salix mucronata subsp. wilmsii are generally associated with the macro channel banks. The Heteropyxis natalensis-Eragrostis gummiflua variant has a total mean canopy cover of $44 \%$.

\subsection{The Heteropyxis natalensis- Chaetachme aristata variant}

The Heteropyxis natalensis-Chaetachme aristata variant occurs on deep (1 $200 \mathrm{~mm}$ ) sandy clay loam soils (21-35\% clay). Above-ground rock cover is restricted to the channel bed and does not occur on the macro channel banks. Diagnostic species include the tree Acacia caffra, the shrub Chaetachme aristata, Clerodendrum glabrum var. glabrum, Cussonia paniculata, Ehretia rigida, Lannea discolor, Osyris lanceolata and Brachylaena rotundata, the dwarf shrubs Rhoicissus tridentata subsp. cuneifolia, Secamone filiformis and the grass Aristida congesta subsp. barbicollis (Species group 4; Table 1). 


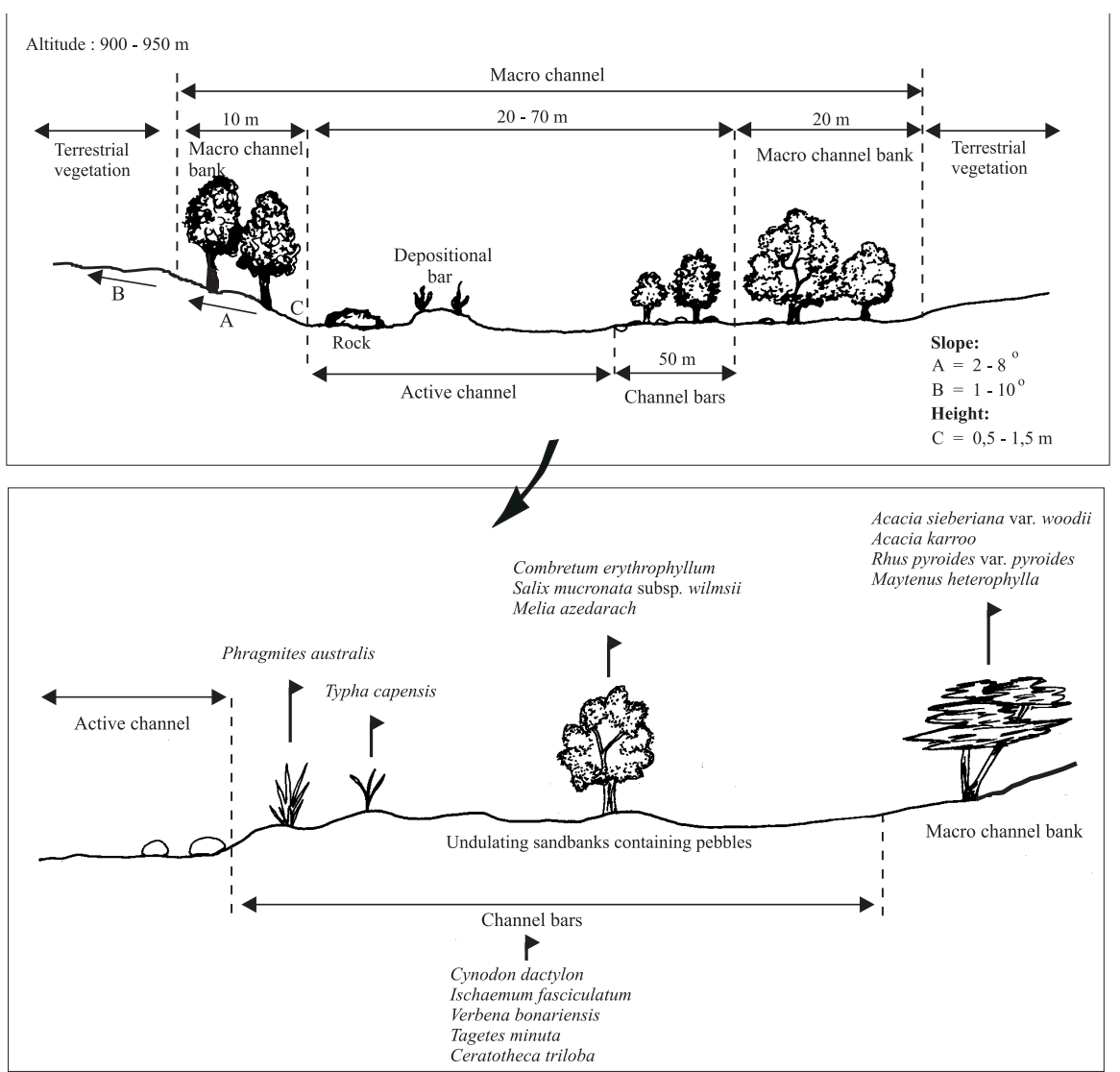

Fig. 5 River profile of the Acacia sieberiana var woodii-Ischaemum fasciculatum woodland.

This variant has a total mean canopy cover of $39 \%$. The woody component, which include the trees, shrubs and dwarf shrubs, contribute $31 \%$ to the total canopy cover of this variant.

\subsection{The Heteropyxis natalensis- Bauhinia galpinii variant}

The Heteropyxis natalensis-Bauhinia galpinii variant is restricted to areas characterised by shallow sandy soils (11-15\% clay). Both the channel bed and macro channel banks have a high above ground rock cover ( $>60 \%$ ) varying from pebbles to boulders. The shrubs Bauhinia galpinii, Flacourtia indica, Ochna sp. and Bridelia mollis are diagnostic for this variant (Species group 5;
Table 1). The tree Ficus ingens var. ingens is also associated with these rocky habitats. The Heteropyxis natalensis-Bauhinia galpinii variant has a total mean canopy cover of $37 \%$.

\section{The Acacia sieberiana var . woodii-} Ischaemum fasciculatum woodland

The Acacia sieberiana var. woodiiIschaemum fasciculatum woodland is represented by eight relevés. It occurs downstream from Loskop Dam to the farm Kameeldoorn (Fig. 2). This woodland is associated with geology from the Transvaal Sequence, Group Rooiberg and the Bushveld Complex (Fig. 1). Soils are predominantly shallow to medium deep (200-500 mm). 
This section of the Olifants River flows through the isolated rocky ridges that are found downstream of Loskop Dam, before levelling off at 900-950 m above sea level. The active channel, which varies between 20 $-70 \mathrm{~m}$ wide, is characterised by depositional bars covered with Phragmites australis (Fig. 5). The channel bars are typical undulating sandbanks with pebbles, while scattered large rocks and boulders are confined to the channel bed. Dense, uninterrupted stands of Phragmites australis dominate the areas adjacent to the active channel. The surrounding catchment area forms part of the Loskop Dam irrigation scheme, with pump houses and channel systems often present.

The diagnostic species of this woodland community (Species group 6; Table 1) include the tree Acacia sieberiana var. woodii. The grass species Cynodon dactylon, Ischaemum fasciculatum, Phragmites australis and forbs Verbena bonariensis, Tagetes minuta and Ceratotheca triloba are prominent on the channel bars. The grass Bothriochloa bladhii and bulrush Typha capensis are mainly restricted to the water edge in the active channel. The exotic invader tree Melia azedarach, although only recorded at four sites, poses a threat to the indigenous vegetation and should be controlled. The total mean canopy cover of the Acacia sieberiana var. woodii-Ischaemum fasciculatum woodland is $74 \%$. The high grass and forb cover values are due to their presence on the channel bars and depositional bars.

\section{The Combretum erythrophyllum- Cynodon dactylon woodland}

The Combretum erythrophyllum-Cynodon dactylon woodland is represented by 28 relevés and it occurs along a large section of the macrochannel. The habitat of this woodland community stretches from the farm Kameeldoorn north of Loskop Dam, to the Burgersfort/Pietersburg national road (Fig. 2). The altitude of this area varies from 900-950 m.

This section of the river is characterised by rocks of the Bushveld Complex (Fig. 1), with deep alluvial sands occurring in the macro channel. The deep (1 $200 \mathrm{~mm})$ soils of the macro channel banks vary from loamy sand (15-20\% clay) to clay soils (>60\% clay.)

Rocks are absent on the soil surface of the macro channel banks but occur together with pebbles within the channel bed. The macro channel of this section of the Olifants River is divided to form an active channel and several seasonal channels with islands in between, which are dominated by woody plant species (Fig. 6).

The reed Phragmites australis totally dominates the channel bars and depositional bars and forms colonies of vegetation approximately five meters wide between the active channel and the macro channel banks. Other species associated with the channel bars and depositional bars include the grasses Cynodon dactylon and Hemarthria altissima and the annual weedy forb Tagetes minuta.

In the Marble-Hall/Groblersdal area, agricultural activities, in the form of intensive irrigated crop production, impact negatively on the riparian vegetation. This is due to the extension of the cultivated fields up to and in many instances into the vegetation associated with the macro channel banks. Pump stations and weirs generally occur in this section of the river.

The section of the Olifants River in the Springbok flats, northwards up to the Strydpoort Mountains including the Arabie Dam, is characterised as a degraded catchment with frequent donga erosion. Destabilisation of certain sections of the macro channel banks occurs as a result of the destruction of natural vegetation through wood collection, informal crop production, and kraal building.

The diagnostic species (Species group 7; Table 1) include amongst others the tree Acacia erioloba and shrub Pavetta lanceolata. The woody component associated with the macro channel banks of this section of the river includes the trees Acacia galpinii, Melia azedarach, Acacia karroo, Combretum erythrophyllum, Ziziphus mucronata 


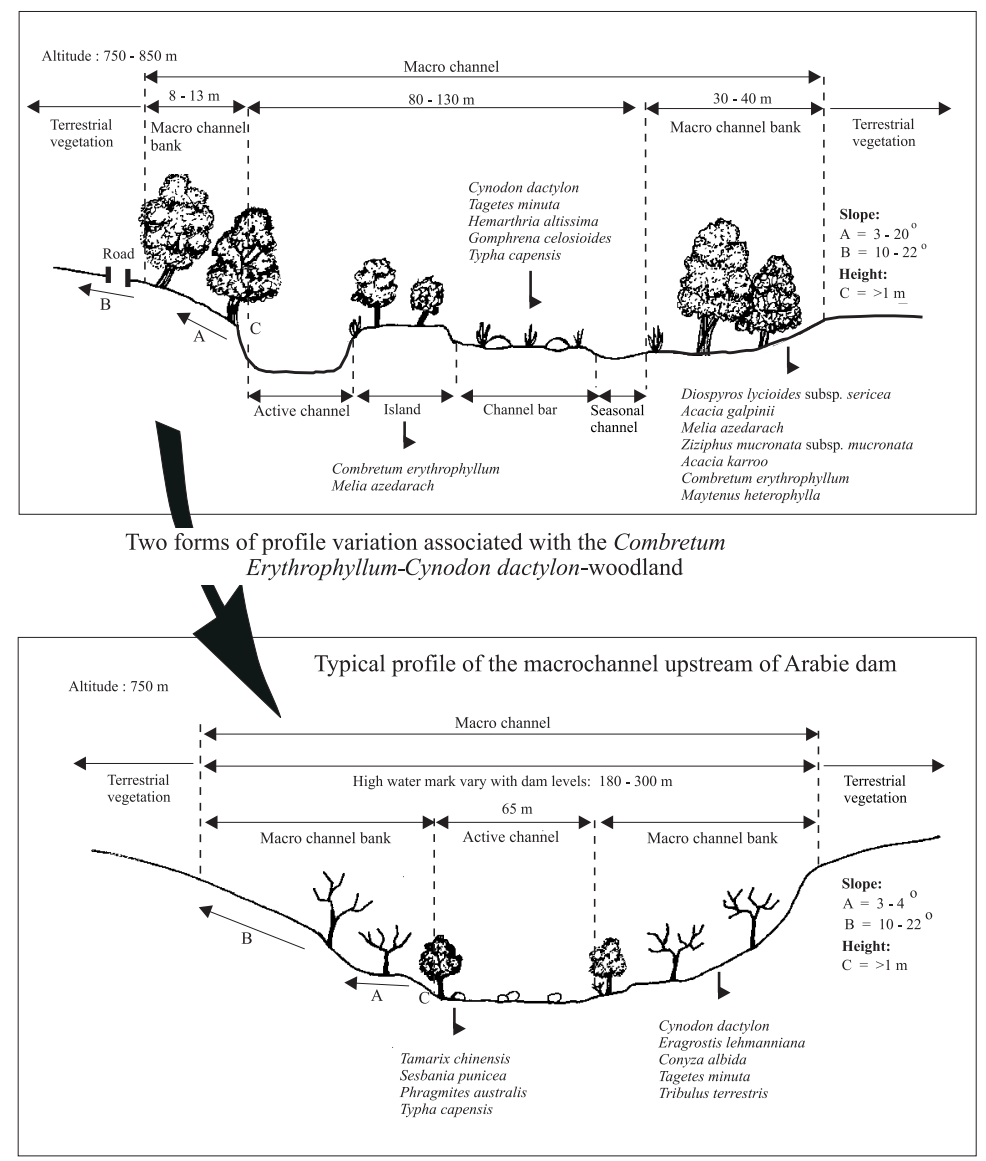

Fig. 6. Variations in river profile characteristic of the Combretum erythrophyllumCynodon dactylon woodland.

subsp. mucronata, the shrubs Fluggea virosa subsp. virosa, Diospyros lycioides subsp. sericea and Gymnosporia buxifolia. The grass species Panicum maximum and forbs Rivinia humilis and Achyranthes aspera var. aspera are associated with the shady areas of the macro channel banks. The exotic invader Melia azedarach is well established in this section of the Olifants River with a mean canopy cover of $2 \%$. The total mean canopy cover of the Combretum erythrophyllumCynodon dactylon woodland is $65 \%$.

This woodland community is divided into six variants. The floristic variation is proba- bly due to the geomorphological variation and the diverse range of human activities characterising the macro channel and adjacent catchment area. The floristic composition of the Combretum erythrophyllumTamarix chinensis variant (variant 4.5) differs for example from the other variants due to the absence of a woody component. The influence of the Arabie Dam and high water levels for prolonged periods have altered the floristic composition and structure of the vegetation upstream of the dam. Most of the woody species were replaced with forb and grass species. 


\subsection{The Combretum erythrophyllum- Rubus sp. variant}

The Combretum erythrophyllum-Rubus sp. variant is restricted to the Ea-Land Type while the other variants occur in the Bc Land Type. Soils of the macro channel banks are $1200 \mathrm{~mm}$ deep with no above-ground rocks. A single active channel with large pools of water is characteristic of the channel bed. Locally the channel bed divides to form an active and seasonal channel with islands separating these channels. These islands are dominated by the tree Combretum erythrophyllum and reed Phragmites australis.

Diagnostic species include Rubus sp. Combretum sp., Solanum mauritianum, Helinus integrifolius and Priva meyeri var. meyeri (Species group 8; Table 1). The distribution of Solanum mauritianum (declared weed) is currently restricted to only a few areas. The declared invader Melia azedarach has seriously encroached into the area and contributes a total of $7 \%$ to the total woody cover $(16 \%)$ of this variant. This species should be removed and eradicated as a high priority. Another declared invader, Sesbania punicea, with a mean canopy cover of $3 \%$ is also considered a serious problem plant within this variant. The Combretum erythrophyllum-Rubus sp. variant has a total mean canopy cover of $72 \%$.

\subsection{The Combretum erythrophyllum- Teramnus labialis subsp. labialis variant}

The Combretum erythrophyllum-Teramnus labialis subsp. labialis variant occurs on those macro channel banks where the soil depth varies from 300 to $1000 \mathrm{~mm}$. The macro channel of this section of the river is characterised by a combination of activeand seasonal channels with a rocky appearance.

The reed Phragmites australis dominates broad areas adjacent to the water edge and the channel bars. Other species that occur on the lower lying channel bars are the grasses Echinochloa crus-galli, Ischaemum fasciculatum, Hemarthria altissima and Bothri- ochloa bladhii and the sedges Cyperus latifolius, Cyperus sexangularis, Typha capensis, Pycreus polystachyos var. polystachyos and the forb Polygonum meisnerianum. Melia azedarach, Acacia galpinii and Ziziphus mucronata subsp. mucronata are the dominant tree species with mean canopy covers of respectively $10 \%, 4 \%$ and $4 \%$. The declared invader Sesbania punicea has a mean canopy cover of $3 \%$ within this variant. Other undesired alien plants are Lantana camara and Ricinus communis. The Combretum erythrophyllum-Teramnus labialis subsp. labialis variant has a total mean canopy cover exceeding $100 \%$ due to the dense woody vegetation stand with overlapping canopies.

\subsection{The Combretum erythrophyllum- Schistostephium heptalobum variant}

The Combretum erythrophyllum-Schistostephium heptalobum variant occurs on macro channel banks with $1200 \mathrm{~mm}$ deep soils, without any rock cover. The channel bed divides to form active and seasonal channels. Both the active and seasonal channels have a rocky appearance due to large boulders and pebbles occurring in the channel beds.

Croplands bordering the macro channel extend into the natural vegetation associated with the macro channel banks, leaving only narrow stretches of natural riparian vegetation on the banks. The reed Phragmites australis forms broad bands on both sides of the active channel and dominates the channel bars. Other prominent species are the grass Hemarthria altissima and the sedges Cyperus latifolius, Cyperus longus var. tenuiflorus, Scirpus burkei, Cyperus sexangularis, Typha capensis and Cyperus fastigiatus. Woody species that are prominent on the macro channel banks include Combretum erythrophyllum, Acacia galpinii, Melia azedarach and Acacia karroo.

Dominant shrub species include Flueggea virosa subsp. virosa, Pavetta lanceolata and Gymnosporia buxifolia. The Combretum erythrophyllum-Schistostephium heptalobum 
variant has a total mean canopy cover of $73 \%$.

\subsection{The Combretum erythrophyllum- Tephrosia polystachya variant}

The Combretum erythrophyllum-Tephrosia polystachya variant is associated with those sections of the macro channel which are characterised by steep macro channel banks and soils of $1200 \mathrm{~mm}$ deep. The channel bed has a rocky and uneven appearance with boulders, pebbles and depositional bars present. Above ground rock cover is however absent from the macro channel banks.

The reed Phragmites australis forms a broad band in the active channel bed bordering the water edge and also dominates the channel bars. Tree species that dominate the macro channel banks include Combretum erythrophyllum, Acacia galpinii, Acacia karroo, Melia azedarach, Gymnosporia buxifolia, Flueggea virosa subsp. virosa, Pavetta lanceolata and Diospyros lycioides subsp. sericea. The grass species Panicum maximum, Setaria verticillata and Dactyloctenium giganteum mainly occur in the shady areas under dense woody vegetation, while Urochloa mosambicensis, Enneapogon scoparius, Schmidtia pappophoroides, Melinis repens, Heteropogon contortus and Era- grostis curvula favour the open areas on the macro channel banks.

The diagnostic species of this variant are Tephrosia polystachya, Cleome hirta, Alternanthera sessilis and Richardia brasiliensis (Species group 11, Table 1). The last two species are weedy and indicate a degree of disturbance. Donga erosion is evident in certain areas. These areas provide habitat for the weedy pioneer forbs Alternanthera pungens, Tagetes minuta, Agremone mexicana, Cirsium vulgare, Schkuhria pinnata and Tribulus terrestris. The Combretum erythrophyllumTephrosia polystachya variant has a total mean canopy cover of $90 \%$.

\subsection{The Combretum erythrophyllum- Tamarix chinensis variant}

The Combretum erythrophyllum-Tamarix chinensis variant is found upstream of Arabie Dam in the vicinity of the Schuinsdraai Nature Reserve. The absence of a woody component is primarily due to the effect of the dam. Woody riparian species that occurred below the water levels when the dam was full to capacity were killed and replaced with grass and forb species. The large areas between the original active channel and the high water mark (Fig. 6) are dominated by the grass species Cynodon

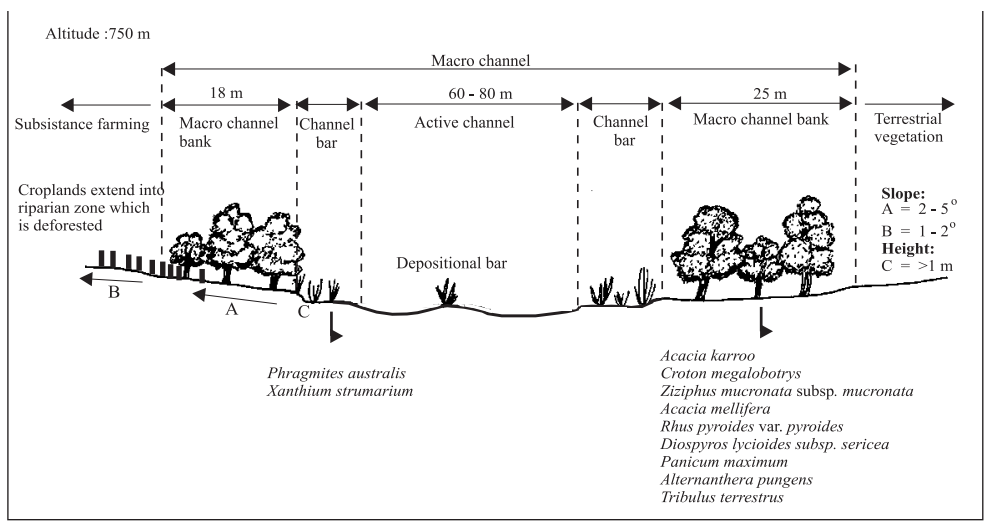

Fig. 7. Cross section indicating the river profile associated with the Acacia mellifera-Urochloa mosambicensis woodland. 
dactylon, Eragrostis lehmanniana and pioneer, weedy forbs Tagetes minuta, Tribulus terrestris and Conyza albida.

The exotic shrub species Sesbania punicea and Tamarix chinensis form narrow dense bands at the water edge. The reed and sedge species Phragmites australis, Typha capensis, Cyperus fastigiatus, Pycreus polystachyos var. polystachyos, Cyperus sexangularis, Cyperus longus var. tenuiflorus and Schoenoplectus tabernaemontani also occur at the water edge. The grasses Cynodon dactylon, Eragrostis lehmanniana and weedy forbs Conyza albida, Tribulus terrestris, Tagetes minuta, Datura stramonium, Verbena bonariensis, Gomphrena celosioides and Schkuhria pinnata dominate the disturbed macro channel banks.

Both the plant species composition and species cover changed due to the influence of the dam. The woody component, which includes the trees, shrubs and dwarf shrubs, has a total mean canopy cover of only $6 \%$. The absence of woody species induced a grass cover of $26 \%$.

\subsection{The Combretum erythrophyllum- Maytenus tenuispina variant}

The Combretum erythrophyllum-Maytenus tenuispina variant occurs on macro channel banks characterised by the absence of a rocky cover, with soil depths of $1200 \mathrm{~mm}$. At places, the main channel divides into two active channels separated by islands, which are dominated by woody vegetation. The tree Faidherbia albida dominates the tree stratum on these islands. Depositional bars characterise the channel bed and are mainly dominated the reed Phragmites australis.

Deforestation occurred in sections of the macro channel where the local people removed woody riparian species associated with the macro channel banks for the building of kraals. This destabilisation of the macro channel banks led to the donga erosion that is so prominent at these sites.

The tree stratum of this variant is dominated by Combretum erythrophyllum, Acacia kar- roo, Ziziphus mucronata subsp. mucronata, Faidherbia albida and Acacia tortilis.

Shrub species present include Gymnosporia buxifolia and Diospyros lycioides subsp. sericea. Grass and sedge species associated with the lower lying channel and depositional bars include Bothriochloa bladhii, Hemarthria altissima, Phragmites australis, Typha capensis and Cyperus sexangularis. The weedy forb species Xanthium strumarium and Datura stramonium are restricted to the seasonal channels and channel bars. The Combretum erythrophyllum-Maytenus tenuispina variant has a total mean canopy cover of $47 \%$. The low cover reflects the impact of vegetation removal, either for the building of kraals or firewood collection.

\section{The Acacia mellifera-Urochloa mosam- bicensis woodland}

The Acacia mellifera-Urochloa mosambicensis woodland is represented by three relevés and is associated with the section of the Olifants River north of the Polokwane/ Burgersfort national road (Fig. 2), also characterised by rocks from the Bushveld Complex (Fig. 1). The river, which flows in an easterly direction, consists of a single active channel bordered by broad channel bars. The reed Phragmites australis and the weedy annuals Xanthium strumarium and Verbesina encelioides var. encelioides dominate these channel bars (Fig. 7).

Soils of the macro channel banks are $1200 \mathrm{~mm}$ deep without an above ground rock cover. Large areas of the surrounding catchment are deforested and are currently used for informal crop production. Woody species that dominate the macro channel banks include Acacia karroo, Croton megalobotrys, Ziziphus mucronata subsp. mucronata and shrub species Acacia mellifera, Rhus pyroides var. pyroides and Diospyros lycioides subsp. sericea. The grass species Panicum maximum, Brachiaria deflexa and forbs Achyranthes aspera var. aspera and Justicia flava are mainly restricted to the shady areas beneath the woody canopy. The open areas of the macro channel 


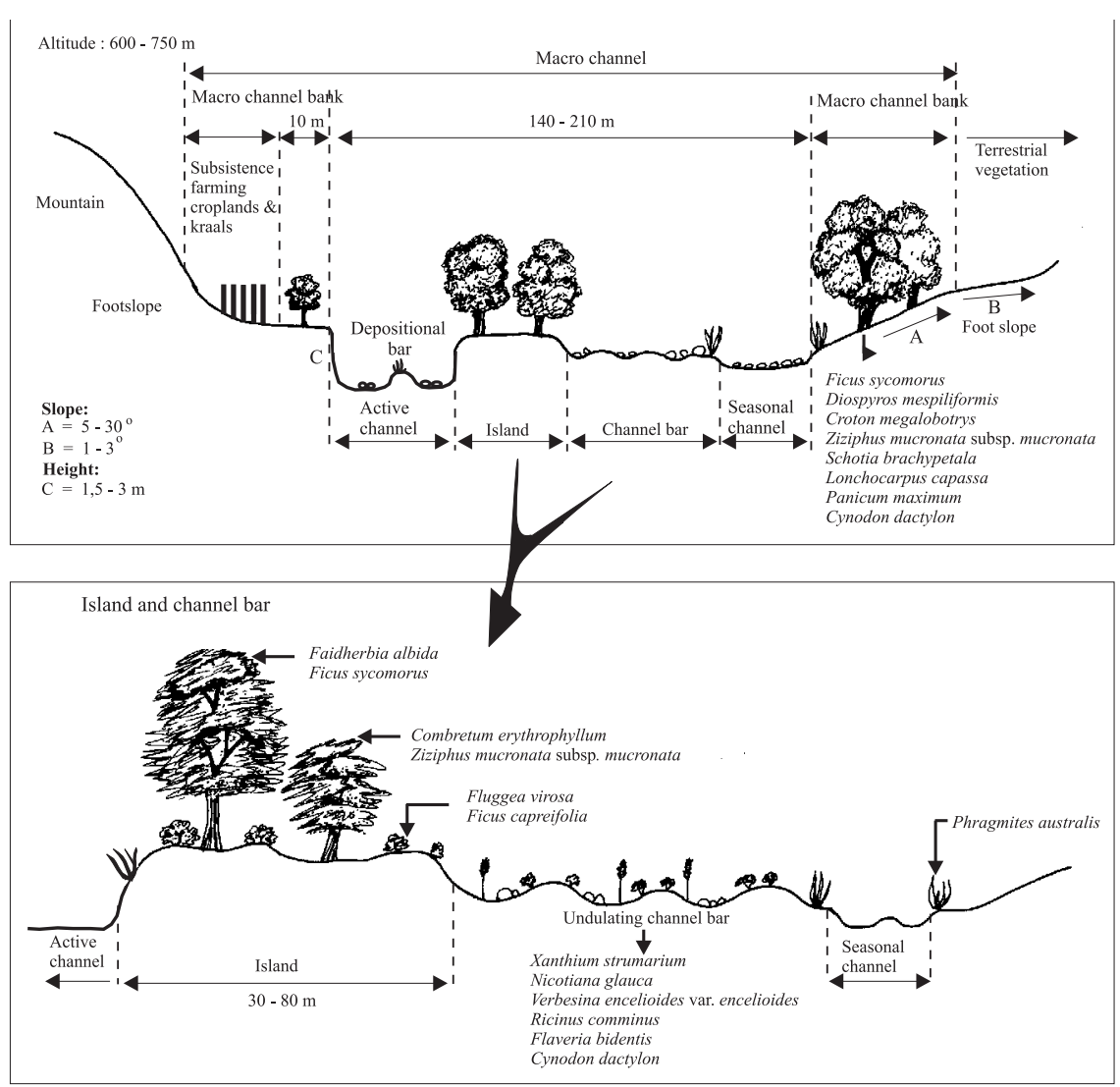

Fig. 8. Cross section of the river profile associated with the Schotia brachypetala-Panicum maximum woodland.

banks are dominated by Cynodon dactylon, Eragrostis pseudosclerantha, Tragus berteronianus, Tribulus terrestris and Alternanthera pungens.

Diagnostic species of this woodland community (Species group 14; Table 1) include the shrub Acacia mellifera and forbs Gisekia pharnacioides var. pharnacioides, Tragia rupestris, Pavonia senegalensis and Coccinia rehmanii. In certain areas the macro channel banks are characterised by the absence of a grass and forb layer enhancing donga erosion due to uncontrolled water runoff. The Acacia mellifera-Urochloa mosambicensis woodland has a total mean canopy cover of $47 \%$. The relative low canopy cover is due to deforestation and over utili- sation of the vegetation of the macro channel banks.

\section{The Schotia brachypetala-Panicum max- imum woodland}

The Schotia brachypetala-Panicum maximum woodland is represented by 30 relevés and is associated with the section of the Olifants River system stretching from Sekhukhuneland up to the mountainous area at the J.G. Strydom tunnel (Fig. 2). The meandering river flows through mountainous terrain at altitudes varying between 600 $-750 \mathrm{~m}$ a.s.l.

The geology along this section of the river is diverse and includes the Pretoria and Chu- 
niespoort Groups of the Transvaal Sequence and rocks from the Bushveld Complex (Fig. 1). Soils of the macro channel banks are from 400-1 $200 \mathrm{~mm}$ deep. The macro channel is typically active with seasonal channels and wide undulating channel bars and islands (Fig. 8). The channel bed has a rocky appearance, while the macro channel banks are without any rock cover.

The islands are dominated by the trees Faidherbia albida, Ficus sycomorus, Combretum erythrophyllum, Ziziphus mucronata subsp. mucronata, Flueggea virosa subsp. virosa and Ficus capreifolia. The reed Phragmites australis dominates the depositional bars. In this community, the macro channel of the Olifants River has been modified to a large extent by intensive agricultural practices. Natural vegetation associated with the macro channel banks is limited to narrow deforested strips. Kraals and croplands stretch up to the channel bed with donga erosion prominent at these sites. The indiscreet removal of woody plants impact negatively on the effectiveness of vegetation in stabilising the channel banks.

The diagnostic trees Ficus sycomorus, Diospyros mespiliformis, Breonadia salicina, Faidherbia albida, Croton megalobotrys, Lonchocarpus capassa, Ziziphus mucronata subsp. mucronata and Schotia brachypetala (Species group 15; Table 1) are characteristic of the macro channel banks. The total mean canopy cover of this woodland community is $52 \%$.

\subsection{The Schotia brachypetala-Carissa bispinosa subsp. zambesiensis vari- ant}

The macro channel associated with this variant varies from a single active channel to various branched channels with islands of up to $80 \mathrm{~m}$ wide. The tree Faidherbia albida is dominant on these islands. Diagnostic species include the shrubs Carissa bispinosa subsp. zambesiensis and Scolopia zeyheri (Species group 16; Table 1).

The woody species Faidherbia albida, Ziziphus mucronata subsp. mucronata, Acacia ataxacantha, Rhus pyroides var. pyroides, Carissa bispinosa subsp. zambesiensis and grass species Panicum maximum, Phragmites australis, Cynodon dactylon and Paspalum distichum are prominent in this variant. The weedy Xanthium strumarium, with a mean canopy cover of $8 \%$, dominates the channel and depositional bars and seasonal channels. The Schotia brachypetala-Carissa bispinosa subsp. zambesiensis variant has a total mean canopy cover of $55 \%$.

\subsection{The Schotia brachypetala- Euphorbia tirucalli variant}

The Schotia brachypetala-Euphorbia tirucalli variant is associated with that section of the macro channel where the macro channel banks form steep rocky footslopes. Medium size to large rocks cover $60 \%$ of the soil surface and soil depth varies between $300-400 \mathrm{~mm}$. The rocky main channel divides into an active and seasonal channel. The vegetation associated with the macro channel banks resembles the surrounding zonal vegetation. The lower lying areas of the macro channel banks are characterised by the tree species Lonchocarpus capassa, Acacia nigrescens and Schotia brachypetala, while Euphorbia tirucalli, Commiphora glandulosa, Commiphora africana var. africana and Aloe globuligemma are conspicuous on the dryer, higher lying areas.

Dominant grass species include Panicum maximum, Urochloa mosambicensis, Cynodon dactylon and Brachiaria deflexa. Xanthium strumarium has a mean canopy cover of less than one percent on the depositional and channel bars. The Schotia brachypetalaEuphorbia tirucalli variant has a total mean canopy cover of $49 \%$.

\subsection{The Schotia brachypetala-Gym- nosporia buxifolia variant}

Typical habitat of the Schotia brachypetalaGymnosporia buxifolia variant is soil that is $500 \mathrm{~mm}$ to $1200 \mathrm{~mm}$ deep, with rocks covering $0-30 \%$ in certain localised areas of the macro channel banks. The river flows through mountainous terrain and the long 


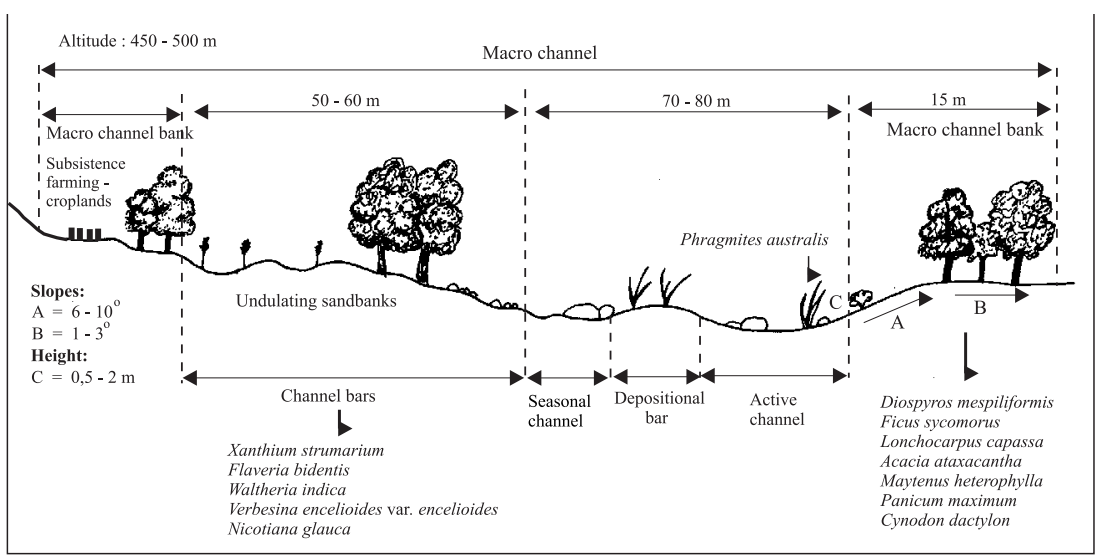

Fig. 9. Cross section of the river profile associated with the Lonchocarpus capassa-Acacia ataxacantha woodland.

rapids associated with this section of the macro channel are typical of a steep gradient.

The channel bed has a rocky appearance and both active and seasonal channels are present. Depositional bars are dominated by Phragmites australis while the weedy Xanthium strumarium, Nicotiana glauca and Verbesina encelioides var. encelioides are prominent in the seasonal channels and channel bars in the macro channel. The Schotia brachypetala-Gymnosporia buxifolia variant has a total mean canopy cover of $49 \%$.

\section{The Lonchocarpus capassa-Acacia atax- acantha woodland}

The Lonchocarpus capassa-Acacia ataxacantha woodland is represented by six relevés and includes the section of the Olifants River downstream of the J.G. Strydom tunnel (Fig. 2). Altitude of the macro channel varies from approximately 450$500 \mathrm{~m}$ above sea level.

This section of the river system is primarily characterised by Makhutswi Gneis (Fig. 1). Soils of the macro channel banks are between 450-1 $200 \mathrm{~mm}$ deep with surface rocks covering up to $45 \%$ of the area, while the active channel contains pebbles and large boulders locally.
The channel bed is divided into active and seasonal channels separated by depositional bars containing large amounts of pebbles. These depositional bars are dominated by Phragmites australis. Bordering the seasonal channel are undulating channel bars transgressing into former islands dominated by woody vegetation (Fig. 9). The weedy forb species Xanthium strumarium, Flaveria bidentis and Waltheria indica and the dwarf shrub species Verbesina encelioides var. encelioides and alien tree species Nicotiana glauca are prominent on these undulating areas.

Diagnostic tree species include Waltheria indica, Sterculia rogersii, Albizia versicolor (Species group 19; Table 1) while Diospyros mespiliformis, Ficus sycomorus, Lonchocarpus capassa, Acacia ataxacantha and Gymnosporia buxifolia dominate the tree and shrub stratums. The total mean canopy cover of the Lonchocarpus capassa-Acacia ataxacantha woodland is $43 \%$.

\section{The Ficus sycomorus-Abutilon angula- tum var. angulatum woodland}

The Ficus sycomorus-Abutilon angulatum var. angulatum woodland is represented by 14 relevés and includes the stretch of river from Mica up to Mamba southeast of Phal- 
aborwa where the Olifants River enters the Kruger National Park (Fig. 2). Altitude varies between 350-450 m above sea level. Makhutswi Gneis is the dominant geological formation (Fig. 1) and soils of the macro channel banks are between 500-1 $200 \mathrm{~mm}$ deep.

The macro channel associated with this woodland community is quite diverse and varies from a channel bed characterised by an active and seasonal channel with depositional bars, channel bars and islands to stretches that include islands and ephemeral channels (Fig. 10). The channel bed has a rocky appearance with pebbles and large boulders often present. Above ground rock cover of $60 \%$ is recorded in areas where rocky foot slopes represent the macro channel banks.

The macro channel and surrounding catchment areas are visibly less disturbed with numerous game farms and nature reserves located in this area. There is a dramatic increase in the number of hippopotami and crocodiles associated with this stretch of river and these animals are often sighted.

The diagnostic species of this woodland community include the trees Cassia abbreviata subsp. beareana and Berchemia discolor (Species group 20; Table 1). Diospyros mespiliformis and Breonadia salicina are dominant on the islands. The higher lying areas of the macro channel banks adjacent to the terrestrial veld are dominated by Spirostachys africana, Acacia nigrescens, Combretum imberbe, Lonchocarpus capassa, Croton megalobotrys, Acacia robusta subsp. clavigera, Grewia sulcata var. sulcata and Gymnosporia buxifolia. The tree species Berchemia discolor, Xanthocercis zambesiaca, Sclerocarya birrea and Lannea schweinfurthii var. stuhlmannii are also present in these areas.

The former islands and channel bars are dominated by Xanthium strumarium, Senna occidentalis, Nicotiana glauca, Cynodon dactylon, Conyza bonariensis, Datura stamonium and Flaveria bidentis. The Ficus sycomorus-Abutilon angulatum var. angula- tum woodland has a total mean canopy cover of $63 \%$.

This woodland community consists of two variants namely the Ficus sycomorus-Eragrostis aspera variant and the Ficus sycomorus-Nuxia oppositifolia variant. The macro channel representing the Ficus sycomorus-Eragrostis aspera variant is characterised by the occurrence of medium to large size rocks while the section associated with the Ficus sycomorus-Nuxia oppositifolia variant mainly contains boulders and rocky sheets. The macro channel banks associated with this variant are also steeper than those recorded for the Ficus sycomorus-Eragrostis aspera variant.

\subsection{The Ficus sycomorus-Eragrostis aspera variant}

The Ficus sycomorus-Eragrostis aspera variant occurs on macro channel banks with soil that varies between 500-1 $200 \mathrm{~mm}$ in depth. The reed Phragmites australis is mainly restricted to the depositional bars, while the islands are dominated by the tree species Ficus sycomorus and Breonadia salicina.

Diagnostic species of this variant include, amongst others, the trees Colophospermum mopane, Ficus abutilifolia and grasses Eragrostis aspera and Eleusine coracana subsp. africana (Species group 21; Table 1). The woody component of the macro channel banks are dominated by Ficus sycomorus, Acacia robusta subsp. clavigera, Acacia nigrescens, Combretum imberbe, Lonchocarpus capassa, Diospyros mespiliformis and Croton megalobotrys. The exotic weeds Nicotiana glauca, Xanthium strumarium and Ricinus comminus dominate the undulating channel bars with mean canopy covers of $6 \%, 3 \%$ and $3 \%$ respectively. Grass species mainly occurring at the water edge and on the channel bars are Sporobolus ioclados, Sporobolus pyramidalis, Bothriochloa insculpta, Hemarthria altissima, Echinochloa colona, Paspalum distichum and Paspalum urvillei. This variant has a total mean canopy cover of $65 \%$. 


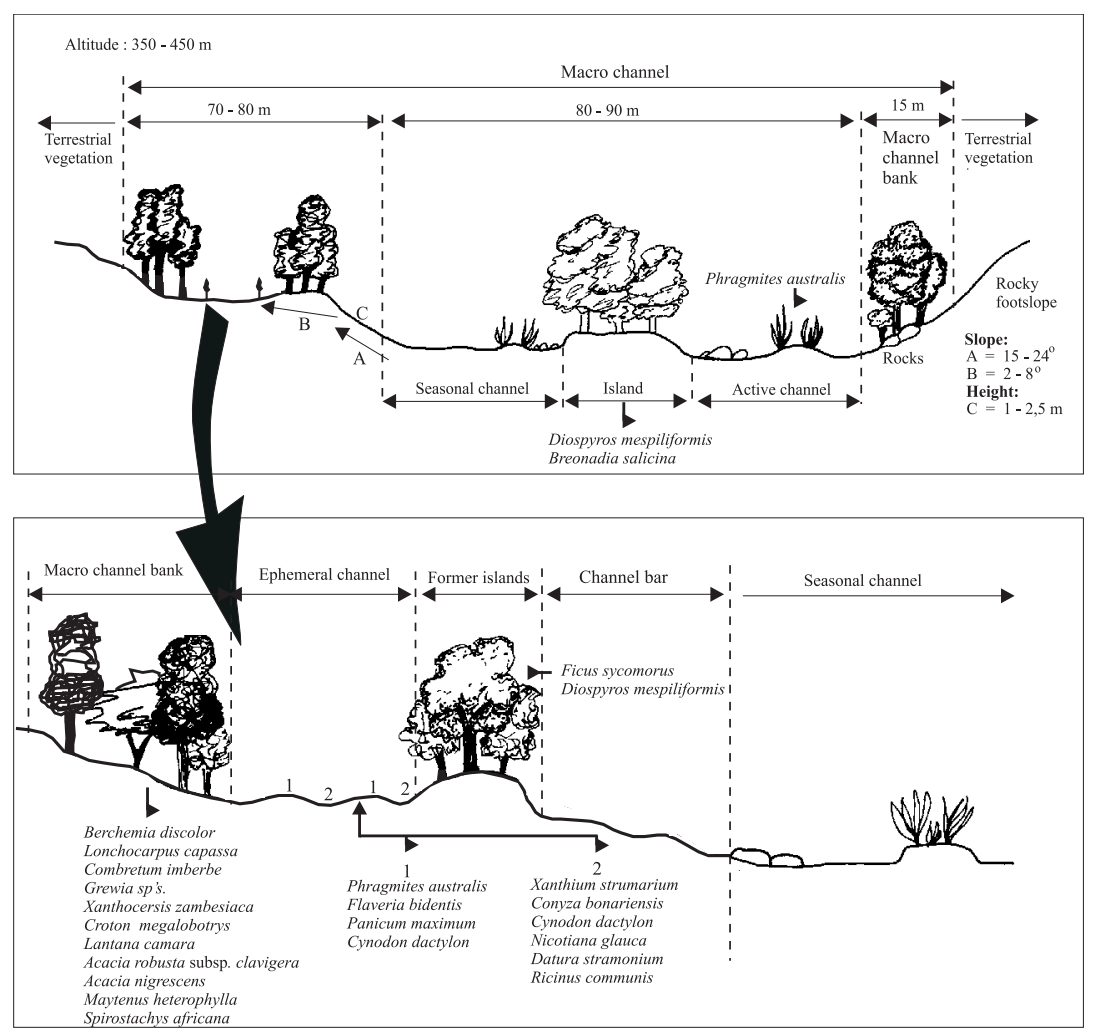

Fig. 10. Schematic representation of a cross section of the river associated with the Ficus sycomorus-Abutilon angulatum var angulatum woodland

\subsection{The Ficus sycomorus-Nuxia oppositifolia variant}

The Ficus sycomorus-Nuxia oppositifolia variant is associated, as is the Ficus sycomorus-Eragrostis aspera variant, with the section of the macro channel of the Olifant River in the Lowveld, characterised by a rocky channel bed, wide channel bars and islands. The tree species Ficus sycomorus and Breonadia salicina dominate the woody component of the islands. Diagnostic species include Nuxia oppositifolia, Maclura africana, Lippia javanica, cf. Cocculus sp. and Manilkara mochisia (Species group 22; Table 1).

Xanthium strumarium, Nicotiana glauca and Ricinus communis dominate the channel bars and seasonal and ephemeral channels. The forb Flaveria bidentis is also associated with the channel bars and ephemeral channels. Plant species mainly occurring at the water edge (active channel) are Hemarthria altissima, Paspalum distichum, Sporobolus ioclados, Paspalum urvillei, Echinochloa colona, Sporobolus pyramidalis and sedges Typha capensis and Cyperus sexangularis. This variant has a total mean canopy cover of $58 \%$.

\section{The Diospyros mespiliformis-Rhus gueinzii woodland}

The Diospyros mespiliformis-Rhus gueinzii woodland is represented by 10 relevés and includes the section of the Olifants River upstream from Mica (Fig. 2). Altitude varies from 450-500 m above sea level. This sec- 


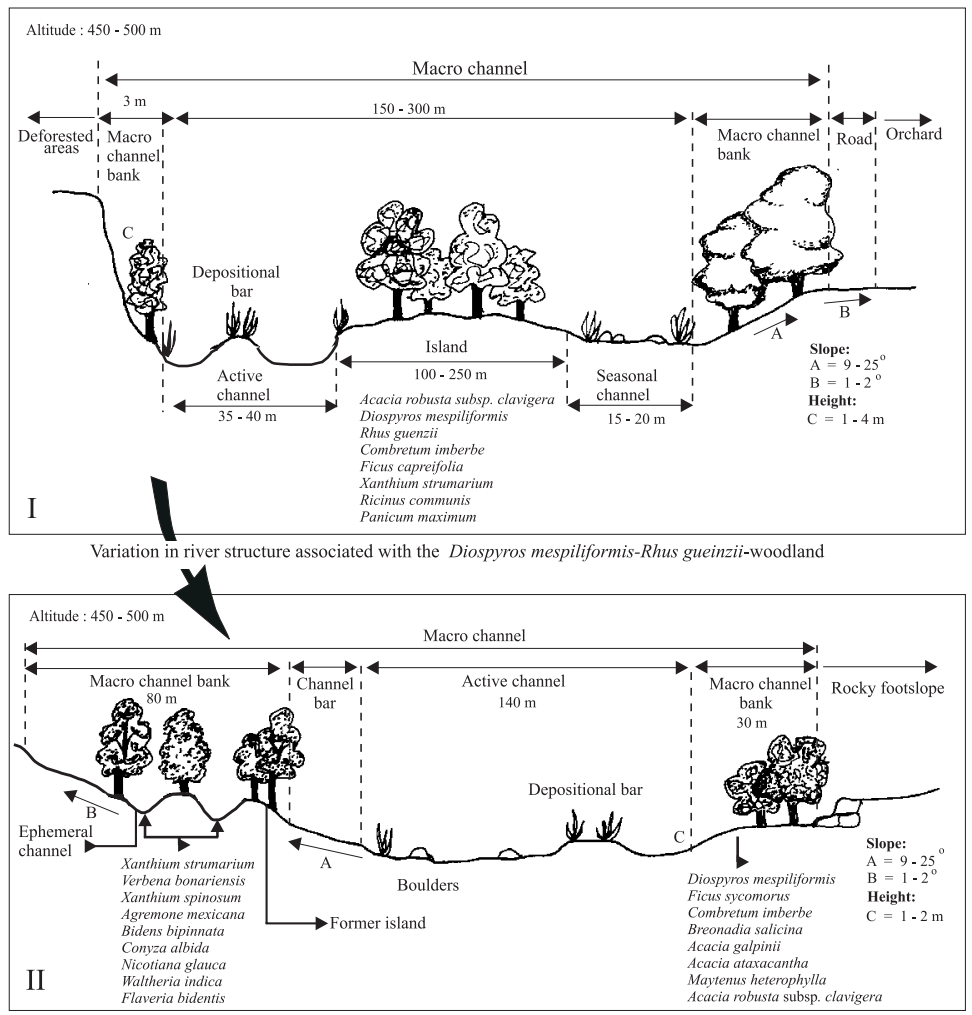

Fig. 11. Cross section of the river characteristic of the Diospyros mespiliformisRhus gueinzii woodland.

tion of the river system is characterised by rocks from the Rooiwater Complex, Mashishimale Suite (Fig. 1) with soils ranging between $500-1200 \mathrm{~mm}$ in depth.

Locally the macro channel divides into an active- and a seasonal channel bordering islands of up to $250 \mathrm{~m}$ wide (Fig. 11). Macro channel banks are predominantly steep and masses of pebbles and large rocks occur in the channel beds. The woody plant species are mainly restricted to the islands, former islands and macro channel banks, while the ephemeral and seasonal channels, depositional bars and channel bars are mainly dominated by herbaceous plants species.

Rhus gueinzii, Eragrostis rigidior and Cleome maculata are diagnostic for this plant community (Species group 23; Table
1). The woody component is dominated by Diospyros mespiliformis, Acacia robusta subsp. clavigera, Ficus sycomorus, Combretum imberbe, Breonadia salicina, Acacia galpinii, Gymnosporia buxifolia and Acacia ataxacantha. The reed Phragmites australis dominates the depositional bars in the channel bed. This woodland community has a total mean canopy cover of $56 \%$.

\section{Conclusion}

The riparian vegetation of the Savanna section of the Olifants River is well developed and visually distinguishable from the surrounding terrestrial zonal vegetation. Both species composition and cover of the vegetation were influenced by the changes in macro channel development of this section 
of the Olifants River System. Diverse floristic variations are found within community boundaries primarily due to the changes in habitat but also as a result of management practices and different forms and intensities of utilisation.

The woody component of the riparian vegetation is mainly restricted to the macro channel banks, islands and former islands. The alluvial landforms such as depositional bars, channel bars and seasonal channels, which vary according to hydrological occurrences at a different time scale, tend to be dominated primarily by annual grass and pioneer forb species, with the exception of a few exotic shrubs species e.g. Nicotiana glauca.

\section{Acknowledgements}

This project was made possible by funds donated by the Water Research Commission and the use of the facilities at the Agricultural Research Council. A special word of thanks to a former collogue and friend for preparing the graphics, Ms. N. Schaap, who passed away recently and to Dr. R.H. Westfall for computer assistance.

\section{References}

AcocKs, J.P.H. 1988. Veld types of Southern Africa. (3rd. ed) Memoirs of the botanical Survey of South Africa 57:1-146.

DEPARTMENT OF Mineral AND ENERgy AfFairs. 1978a. 1:250 000 Pretoria Geological Map (2528). Pretoria: Government Printer.

Department of Mineral and Energy Affairs. 1978b. 1:250 000 Nylstroom Geological Map (2428). Pretoria: Government Printer.

Department of Mineral and Energy Affairs. 1986a. 1:250 000 East Rand Geological Map (2628). Pretoria: Government Printer.

DePARTMENT OF Mineral and ENERgy AfFAirs. 1986b. 1:250 000 Pilgrim's rest Geological Map (2428). Pretoria: Government Printer.
MybuRGH, W.J. 2000. Oewerplantegroei van the Olifantsriviersisteem - 'n Ekologiese perspektief. Pretoria: Waternavorsingskommissie. (Memoir. ISBN No 186845 5688).

Myburgh W.J. 2001. The ekologie en plantegroeibestuur van the Olifantsriviersisteem. $\mathrm{PhD}$ thesis, University of Pretoria, Pretoria.

Myburgh, W.J. \& Bredenkamp, G.J. in press. The distribution and extent of declared weeds and invader plants in the macro channel of the Olifants River System, Mpumalanga. Koedoe.

Myburgh, W.J. \& G.J. BRedenKAMP. 2004. Macrochannel riparian vegetation of the Olifants River System in the Grassland Biome, Mpumalanga. Koedoe 47(1): 41-54.

Naiman, R.J., H. Decamps, J. PAstor \& A.C. JOHNSTON. 1988. The potential importance of boundaries to fluvial ecosystems. Journal of the North American Benthological Society 7: 289-306.

Nillson, C., A. Ekblad, M. Dynesius, S. Backe, M. GardfJell, B.CARlberg, S. Hellqvist \& R. JANSSON. 1994. A comparison of species richness and traits of riparian plants between a main river channel and its tributaries. Journal of Ecology 82: 281-295.

RUTHERFORD, M.C. \& R.H. WeSTFALL. 1986. Biomes of Southern Africa - an objective categorization. Memoirs of the Botanical Survey of South Africa 54: 45-65.

TownSEND, C.R. 1989. The patch dynamics concept of stream community ecology. Journal of the North American Benthological Society 8: 36-50.

Vannote, R.L., G.W. Minshall, K.W. Cummins, J.R. Sedell \& C.E. Cushing. 1980. The river continuum concept. Canadian Journal of Fisheries and Aquatic Science 37:130-137.

WARD, J.V. \& J.A. STANFORD. 1987. The ecology of regulated streams: past accomplishments and directions for future research. Pp. 391-409. In: Craig, J.F. \& J.B. Kemper (eds.). Regulated Streams. Advances in Ecology. New York: Plenum Press.

Westfall, R.H. 1990. Phytotab-PC: A program package for vegetation classification and mapping. ARC - Range and Forage Institute, P/Bag X05, Lynn East, 0039. 